I nvest i gat $i$ on of associ at $i$ on bet ween mercury sensi ti zat i on and HLA- DR6

\begin{tabular}{|c|c|}
\hline 著者 & $\begin{array}{l}\text { SATO Kazuhi r o, KUSAKA Yuki nor i, ZHANG Qunwei } \\
\text { YANAG HARA Nakot o, UEDA Kei i chi, MORI HI RO } \\
\text { H r onor i , I SH I Yasuo }\end{array}$ \\
\hline $\begin{array}{l}\text { jour nal or } \\
\text { publ i cat } i \text { on titl e }\end{array}$ & Cont act der mat i t i s \\
\hline vol une & 34 \\
\hline number & 4 \\
\hline page $r$ ange & 295 \\
\hline year & 1996-04 \\
\hline URL & ht t p: //hdl . handl e. net /10098/5220 \\
\hline
\end{tabular}




\title{
Investigation of the association between mercury sensitization and HLA-DR6
}

\author{
Kazuhiro Sato', Yukinori Kusaka', Qunwei Zhang', Makoto Yanagihara ${ }^{2}$, Keilchi Ueda ${ }^{2}$, \\ HIRONORI MORIHIRO ${ }^{3}$ AND YASUO ISHII ${ }^{3}$ \\ Departments of 'Environmental Health, ${ }^{2}$ Dermatology and ${ }^{3}$ Dental Surgery, Fukui Medical School, \\ Matsuoka-cho, Fukui 910-11, Japan
}

Key words: mercury sensitization; patch test; HLA-DR; epidemiology; immunological basis; genetic basis. (C) Munksgaard, 1996.

HLA molecules, polymorphic membrane glycoproteins, are classified into 2 groups: those expressed on the surface of almost all nucleated cells (HLA class I molecules), and those found on the surface of cells mainly involved in the immune response (HLA class II molecules) (1). In guinea pigs and mice, the genes that control delayed hypersensitivity reactions have been shown to be linked with those of the major histocompatibility antigens (2). The immune response genes (Ia) of mice have their homologues in the human HLA-DR locus. Although significant increases in HLA-DRw6 antigen in nickel-contact-sensitive patients have been reported (3), other attempts to investigate the link between HLA typing and metal contact sensitivity have resulted in conflicting results for nickel, cobalt and chromium (1). However, there have been no reports of previous investigations of the association between mercury sensitization and HLA-DR.

Previously (4), we investigated various factors related to mercury sensitization of 156 , 4th year medical students between 1993 and 1994. We found that mercurysensitized students had a significantly higher frequency of eczema caused by cosmetics, shampoos, soaps and hair creams, and had significantly more teeth modified with metals compared to controls. In addition, their urinary mercury concentrations were significantly higher than those of the non-sensitized group. However, mercury sensitization was not significantly associated with

Table 1. Results of serological HLA-DR typing in mercurysensitized subjects $(n=20)$, with reference to non-sensitized controls $(n=22)$ and the general Japanese population $(n=898)$

\begin{tabular}{lccc}
\hline $\begin{array}{l}\text { HLA-DR } \\
\text { antigens }\end{array}$ & $\begin{array}{c}\text { No. Hg- } \\
\text { sensitized } \\
\text { students (\%) }\end{array}$ & $\begin{array}{c}\text { No. Hg } \\
\text { non-sensitized } \\
\text { students (\%) }\end{array}$ & $\begin{array}{c}\text { No. general } \\
\text { Japanese } \\
\text { population (\%) }\end{array}$ \\
\hline DR1 & $1(5)$ & $2(9.1)$ & $96(10.7)$ \\
DR2 & $9(45)$ & $8(36.4)$ & $300(33.4)$ \\
DR3 & $0(0)$ & $1(4.5)$ & $4(0.4)$ \\
DR4 & $7(35)$ & $9(40.9)$ & $363(40.4)$ \\
DR5 & $3(15)$ & $3(13.6)$ & $167(18.6)$ \\
DR6 & $9(45)$ & $6(27.3)$ & $231(25.7)$ \\
DR7 & $1(5)$ & $0(0)$ & $7(0.8)$ \\
DR8 & $1(5)$ & $4(18.2)$ & $223(24.8)$ \\
DR9 & $4(20)$ & $6(27.3)$ & $218(24.3)$ \\
DR10 & $0(0)$ & $1(4.5)$ & $11(1.2)$ \\
\hline
\end{tabular}

Type I allergic diseases. In the present study, we examined 215,4 th year students in 1995 and investigated various factors relating to mercury sensitization. We also performed serological HLA-DR typing of 20 mercurysensitized and 22 non-sensitized students as controls in the present study.

The rate of mercury sensitization was $13.0 \%$ (28/215). The prevalences of HLA-DR types in the mercury-sensitized and non-sensitized students in this study and in the general Japanese population (5) are summarized in Table 1. We found an increase in DR6 among the present subjects. However, there were no significant differences in incidence of any of the HLA-DR types between mercury-sensitized and non-sensitized students or the general Japanese population (by the $\chi^{2}$ test).

Although we found an increase in DR6, there were no significant differences in any of the HLA-DR types between the 2 groups. Therefore, we could not reach a definitive conclusion with regard to DR antigens. If a definite association of HLA type was found with metal sensitivity, preventive methods (e.g., antigen exclusion therapy) could be used from childhood in subjects who had the HLA type. More extensive research is needed to clarify the associations between HLA types and metal sensitivity by using DNA sequence assays.

\section{References}

1. Emtestam L, Zetterquist H, Olerup O. HLA-DR, -DQ and -DP alleles in nickel, chromium, and/or cobalt-sensitive individuals: genomic analysis based on restriction fragment length polymorphisms. J Invest Dermatol 1993: 100: $271-274$

2. Polak L, Barnes J M, Turk J L. The genetic control of contact sensitization to inorganic metal compounds in guinea pigs. Immunology 1968: 14: 707-711.

3. Mozzanica N, Rizzolo L, Veneroni G, Diotti R, Hepeisen S, Finzi A F. HLA-A, B, C and DR antigens in nickel contact sensitivity. Br J Dermalol 1990: 122: 309-313.

4. Sato K, Kusaka Y, Yanagihara M, Ueda K, Mori T, Miyakoshi $\mathrm{S}$. An epidemiologic study of factors relating to mercury sensitization. Jpn J Allergy 1995: 44: 86-92.

5. Imanishi T, Akaza T, Kimura A, Tokunaga K, Gojobori T. HLA 1991. Proceedings of the 11th International Histocompatibility Workshop and Conference, vol. 1. Tsuji K, Aizawa M, Sasazaki T (eds): Oxford: Oxford Science Publications, 1991: 1065-1220. 